\title{
Design of Polymeric Antiscalants Based on Functional Vinyl Monomers for (Fe, Mg) Silicates
}

\author{
Gökhan Topçu, ${ }^{\dagger}$ Aslı Çelik, ${ }^{\dagger}$ Alper Baba, ${ }^{\dagger}$ and Mustafa M. Demir*,†॰ \\ ${ }^{\dagger}$ Department of Materials Science and Engineering and ${ }^{\ddagger}$ Department of Civil Engineering, İzmir Institute of Technology, 35430 \\ Gülbahçe, Urla, İzmir, Turkey
}

\section{Supporting Information}

ABSTRACT: Silica/silicate scaling is one of a few detrimental problems that cause high economical loss in the geothermal and petroleum fields. The prevention of silica/silicate has been attempted using antiscalants with functional groups, particularly $-\mathrm{NH}_{2}$; however, metal silicates are commonly found in the fields, and the antiscalants developed thus far are not effective against these compounds. In this work, polymeric antiscalants have been developed by merging two or more functional comonomers consisting of various chelating groups for metal cations. Homo- and copolymers of acrylamide (AM), the sodium salt of vinyl sulfonic acid (VSA), and vinyl phosphonic acid (VPA) were synthesized to examine their antiscaling performance against metal silicate scaling. Lab-scale metal silicates were obtained in a pressured autoclave reactor. The antiscalants were tested at various dosages $(25,50$, and $100 \mathrm{ppm})$, and their effects were investigated from the leftover decantates after isolation of the solid precipitates. The polymeric antiscalants were found to be particularly effective against metal silicates and ineffective against simple silica precipitates. Acidic groups may be coordinating the metal cations, which prevents the formation of precipitates. Among these acidic comonomers, VSA-containing polymers, in particular, increased the solubility of metal silicates.

\section{INTRODUCTION}

Silicate scaling is frequently observed in the production and injection wells of both petroleum and geothermal fields. The decrease of the temperature and pressure during production reduces the solubility of siliceous species and causes remarkable precipitation, namely, scaling. ${ }^{1}$ For the last 2 decades, mineral scaling in petroleum and geothermal power plants has become the most common and troublesome damage-causing problem because deposition of silicates on the surface of important plant parts, such as pipes, separator vessels, and heat exchangers, blocks the fluid flow through the system and decreases the productivity of the oilfield wells. ${ }^{2,3}$ Siliceous deposits are stubborn and can be usually dissolved in HF, because HF is effective at cleaving the $\mathrm{Si}-\mathrm{O}$ bond. ${ }^{4-6}$ Geothermal fluids are saturated with silica and are typically close to saturation with magnesium silicate, aluminum silicates, opaline silica, ironmagnesium silicates, and metal sulfides; ${ }^{7-9}$ thus, metal silicate deposits may exist in various and complicated forms depending upon the specific chemical composition of geothermal and/or petroleum fields. ${ }^{10-13}(\mathrm{Fe}, \mathrm{Mg})$ silicate is one of the densest deposits $\left(\sim 2.6 \mathrm{~g} / \mathrm{cm}^{3}\right)$ when compared to other deposits, such as carbonates and sulfides.

A common remedy for the prevention of deposit formation is the application of either acids or scale inhibitors. The dosage of acids to any system is critical because the chemistry, concentration, and dosage placement need to be studied very carefully because corrosion may readily occur in an acidic environment. ${ }^{14,15}$ Amorphous silica precipitates/deposits could be envisioned as products of silicic acid/silicate polycondensation, which involves nucleophilic attack of monomeric silica; hence, ionic interactions between silicic acid and inhibitors have a critical role in mitigating silica scaling. ${ }^{16-18}$
Various antiscalants have recently been employed for brine treatment. They are commonly ${ }^{19,20}$ macromolecules, such as polymers and dendrimers, ${ }^{14}$ containing cationic groups, such as inulin and polyaminoamide (PAMAM). Demadis et al. reported that cationic inulin (CATIN) polymer has positively charged quaternary ammonium groups, and they tested the polymer for silica inhibition activity. The degree of substitution (DS, average number of cationic groups per monomer) values of CATIN 1, 2, and 3 polymers were $0.22,0.86$, and 1.28, respectively, and each was tested at 40,80 , and 100 ppm dosage levels. The inhibition performance was claimed to be directly related to dosage and DS values. The best result was found at $40 \mathrm{ppm}$ of CATIN 2 and 3 (DS $=0.86$ and 1.28, respectively). ${ }^{21}$

The inhibitory activity of dendrimers, because of their structural properties, has been investigated in many studies. ${ }^{22-25}$ PAMAM dendrimers have amine groups on branches with different growth generations around a central core. These amide linkages were claimed to interact with the negatively charged silica. ${ }^{22}$ The antiscaling performance of PAMAM dendrimers, those that have different functional groups $\left(-\mathrm{NH}_{2}\right.$ and $-\mathrm{COOH}$ ), were studied by Demadis et al. The effects of $-\mathrm{COOH}$ groups and different dendrimer generations were insignificant on silica-scale prevention because repulsive forces act between anionic silica particles and the $-\mathrm{COO}^{-}$groups. The test experiments were performed at $500 \mathrm{ppm}$ initial $\mathrm{SiO}_{2}$ concentration. The results were recorded for both short $(8 \mathrm{~h})$ and long $(72 \mathrm{~h})$ term time periods. $-\mathrm{NH}_{2}$-terminated PAMAM dendrimers showed a remarkable effect on silica (310 ppm)

Received: April 27, 2017

Revised: June 30, 2017

Published: July 3, 2017 
<smiles>C=CC(N)=O</smiles>

acrylamide<smiles>C=CS(=O)(=O)[O-]</smiles>

vinyl sulfonic acid sodium

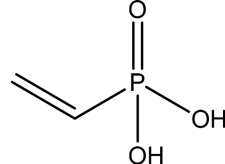

vinyl phosphonic acid

Figure 1. Molecular structure of the comonomers.

with respect to the solubility limit of silica of the control test experiment $(\sim 150 \mathrm{ppm})$. Although performances of $-\mathrm{NH}_{2}$ terminated PAMAM dendrimers are promising, there is a threshold dose level. Furthermore, the PAMAM dendrimer experiments support the importance of ionic interactions over silica scaling by their generation. ${ }^{23}$ The higher cationic charge densities resulted in polycation-anionic silica entrapment and precipitation because the cationic $-\mathrm{NH}_{3}{ }^{+}$groups attract with anionic silicate groups. ${ }^{23,24}$ An anionic comonomer [carboxymethyl inulin (CMI)] was added to reduce the formation of the PAMAM- $\mathrm{SiO}_{2}$ complex. The anionic groups $\left(-\mathrm{COO}^{-}\right)$on the CMI polymer neutralize the $-\mathrm{NH}_{3}{ }^{+}$groups on the PAMAM dendrimer and prevent the association of $-\mathrm{NH}_{2}$ groups and the $\mathrm{SiO}_{2}$ matrix (deactivation). ${ }^{14,24}$ The effect of cationic charge density on the mitigation of the silica scale was tested with poly(allylamine hydrochloride) (PALAM), polyacrylamide-co-diallyldimethylammonium chloride (PAMALAM), and polyethylene imine (PEI). Control test experiments were performed with an initial $\mathrm{SiO}_{2}$ concentration of $500 \mathrm{ppm}$. The cationic charge density of PEI had $25 \%$ primary, $50 \%$ secondary, and $25 \%$ tertiary amine functionalities. PAMALAM had acrylamide groups with 55 wt \%, and PALAM mainly had primary amine groups. These amine groups on PEI and PALAM were associated with anionic silica particles. The optimum dosage levels were inversely proportional with cation density, which were 10, 20, and 80-100 ppm for PEI, PALAM, and PAMALAM, respectively. Above the optimum dosage levels, fluffy insoluble flocculants appeared and the inhibitory activities of the related molecules decreased. ${ }^{26}$

The inhibition performance of an adipic acid/amineterminated polyether D230/diethylenetriamine copolymer (AA/AT/DE) and polyepoxy succinic acid (PESA) blend was studied by Zhang et al. ${ }^{15}$ The AA/AT/DE polymer has mainly $-\mathrm{NH}$ groups that make it a potential silica inhibitor. The test experiments for $\mathrm{AA} / \mathrm{AT} / \mathrm{DE}$ resulted in the observation of white flocculants. To overcome the detrimental effect of excess positive charge density, anionic PESA was added. The inhibition performance was maximized upon application of 20 ppm of PESA along with $40 \mathrm{ppm}$ of AA/AT/DE.

Although the silica-scaling inhibitors exhibit promising effects, they are less effective against metal silicate scaling. The presence of metal cations, i.e., water hardness, increases the rate of metal silicate precipitation compared to normal (soft) water. Silica concentrations were tested with different $\mathrm{Ca} / \mathrm{Mg}$ ratio solutions. ${ }^{27}$ For this reason, the effects of the metal contribution will be the main focus for metal-silicate-scaling inhibition. Water-soluble polymers that contain ligands on the main or side chains were synthesized for the sequestering of metal ions. ${ }^{28-31}$ In this study, homo- and copolymers of functional comonomers of vinyl sulfonic acid sodium salt (VSA), vinyl phosphonic acid (VPA), and acrylamide (AM) were synthesized. The antiscaling performances of the three homopolymers, three copolymers, and one terpolymer were examined at various dosages, taking into account the solubility of silica and metal cations in the decantate.

\section{EXPERIMENTAL SECTION}

2.1. Materials. AM, VSA solution ( $25 \mathrm{wt} \%$ ), and VPA were used as comonomers for polymer synthesis. The molecular structures of the comonomers are given in Figure 1. Ammonium persulfate (APS) and 4,4'-azobis(4-cyanovaleric acid) (ACVA) were used as polymerization initiators. Polymer chains were precipitated in equivolume mixtures of methanol and acetone. All chemicals and solvents were purchased from Sigma-Aldrich (St. Louis, MO, U.S.A.) and were used as received without any further purification. The deionized water $\left(18.2 \mathrm{M} \Omega \mathrm{cm}^{-1}\right.$ at $25{ }^{\circ} \mathrm{C}$ ) used in all experiments was produced by a Milli- $Q$ Advantage water treatment system.

$\mathrm{FeCl}_{2} \cdot 4 \mathrm{H}_{2} \mathrm{O}$ and $\mathrm{MgCl}_{2} \cdot 6 \mathrm{H}_{2} \mathrm{O}$ were purchased from Merck (Kenilworth, NJ, U.S.A.), $\mathrm{CaCl}_{2}$ and $\mathrm{Na}_{2} \mathrm{CO}_{3}$ were obtained from Sigma-Aldrich (St. Louis, MO, U.S.A.), and $\mathrm{Na}_{2} \mathrm{SiO}_{3}$ (35.5 wt \% in $\mathrm{H}_{2} \mathrm{O}$ ) was obtained from Carl Roth (Karlsruhe, Germany). Reagentgrade $\mathrm{Na}$ silicate solution was diluted with distilled water to yield approximately $2 \mathrm{~g} / \mathrm{L} \mathrm{SiO}_{2}$.

2.2. Methods. 2.2.1. Synthesis of Antiscalants. AM (1 g, 14 $\mathrm{mmol})$ was dissolved in distilled water $(20 \mathrm{~mL})$, and the solution was bubbled with $\mathrm{N}_{2}$ for 10 min. Subsequently, ammonium persulfate ( $31.9 \mathrm{mg}, 0.14 \mathrm{mmol}$ ) was added to the system as an initiator. The reaction was maintained at $55^{\circ} \mathrm{C}$ for $25 \mathrm{~min}$ in a Schlenk flask that was equipped with a condenser, and the reaction environment was maintained under $\mathrm{N}_{2}$. The obtained viscous liquid was precipitated by dropwise addition into $50 \mathrm{~mL}$ of methanol. Afterward, the precipitated polyacrylamide (PAM) was filtered and dried at $50{ }^{\circ} \mathrm{C}$ for $12 \mathrm{~h}$.

Solution polymerization of poly(vinyl sulfonic acid) sodium (PVSA) has been described elsewhere. ${ }^{32}$ Briefly, $4 \mathrm{~g}(2.52 \mathrm{M})$ of VSA solution and APS $(16.5 \mathrm{mg}, 0.07 \mathrm{mmol})$ were loaded into a Schlenk flask and bubbled through with $\mathrm{N}_{2}$ for $10 \mathrm{~min}$. The mixture was stirred at $50{ }^{\circ} \mathrm{C}$ for $12 \mathrm{~h}$ and quenched. PVSA was precipitated by dropwise addition of the mixture into $40 \mathrm{~mL}$ of methanol. PVSA was obtained after centrifugation of the mixture at $6000 \mathrm{rpm}$ for $30 \mathrm{~min}$, and the precipitate was dried at $50{ }^{\circ} \mathrm{C}$ for $2 \mathrm{~h}$ after filtration.

The synthesis of poly(vinyl phosphonic acid) (PVPA) was carried out as described in refs 33 and 34 . VPA $(1.08 \mathrm{~g}, 10 \mathrm{mmol})$ was diluted by distilled water $(0.5 \mathrm{~mL})$. The mixture was purged from oxygen via $\mathrm{N}_{2}$ treatment. ACVA was added to the mixture, and the reaction was maintained at $85{ }^{\circ} \mathrm{C}$ for $4 \mathrm{~h}$. Subsequently, the mixture was dialyzed through a cellulose membrane $\left(M_{\mathrm{w}}=12 \mathrm{~kg} / \mathrm{mol}\right.$ cut-off $)$ to remove unreacted monomer from the system. PVPA chains were obtained by lyophilization, and the obtained solid was dried at $40{ }^{\circ} \mathrm{C}$ for $2 \mathrm{~h}$.

For the synthesis from AM and VPA monomers, AM (0.54 g, 7.6 $\mathrm{mmol})$ and VPA (0.82 g, $7.6 \mathrm{mmol})$ were measured into $20 \mathrm{~mL}$ of distilled water. The mixture was purged by $\mathrm{N}_{2}$ for $10 \mathrm{~min}$. APS ( 34.7 $\mathrm{mg}, 0.152 \mathrm{mmol}$ ) was used as an initiator, and the reaction was maintained at $50{ }^{\circ} \mathrm{C}$ for $12 \mathrm{~h}$. Poly(acrylamide-co-vinyl phosphonic acid) $[\mathrm{P}(\mathrm{AM}-\mathrm{co}-\mathrm{VPA})]$ was precipitated in ethanol and dried at $45{ }^{\circ} \mathrm{C}$ for $24 \mathrm{~h}$.

$\mathrm{AM}(0.54 \mathrm{~g}, 7.6 \mathrm{mmol})$ and VSA $(4 \mathrm{~g}, 7.6 \mathrm{mmol})$ were diluted into $20 \mathrm{~mL}$ of distilled water, and $\mathrm{N}_{2}$ was bubbled through for $10 \mathrm{~min}$. APS $(34.7 \mathrm{mg}, 0.152 \mathrm{mmol}$ ) was added to the system, and the reaction was carried out at $55{ }^{\circ} \mathrm{C}$ for $12 \mathrm{~h}$. The resulting colorless solution was added dropwise into methanol to precipitate white poly(acrylamide-covinyl sulfonic acid) $[\mathrm{P}(\mathrm{AM}-\mathrm{co}-\mathrm{VSA})]$. The product was filtered and then dried at $50{ }^{\circ} \mathrm{C}$ for $12 \mathrm{~h}$. 
Table 1. Detailed Approaches to Antiscalant Synthesis

\begin{tabular}{|c|c|c|c|c|c|c|}
\hline & $\mathrm{AM}(\mathrm{g})$ & VSA (g) & VPA $(g)$ & temperature $\left({ }^{\circ} \mathrm{C}\right)$ & molar ratio of initiator (APS, ACVA*) (\%) & yield (\%) \\
\hline PAM & 1 & - & - & 55 & 1 & 85 \\
\hline PVSA & - & 4 & - & 50 & 1 & 90 \\
\hline PVPA & - & - & 1.08 & 85 & $1^{*}$ & 60 \\
\hline $\mathrm{P}(\mathrm{AM}-c o-\mathrm{VSA})$ & 0.54 & 4 & - & 55 & 1 & 80 \\
\hline $\mathrm{P}(\mathrm{VSA}-c o-\mathrm{VPA})$ & - & 4 & 0.82 & 60 & 1 & 65 \\
\hline $\mathrm{P}(\mathrm{AM}-c o-\mathrm{VPA})$ & 0.54 & - & 0.82 & 50 & 1 & 60 \\
\hline $\mathrm{P}(\mathrm{AM}-c o-\mathrm{VSA}-c o-\mathrm{VPA})$ & 0.71 & 5.2 & 1.08 & 60 & 1 & 50 \\
\hline
\end{tabular}

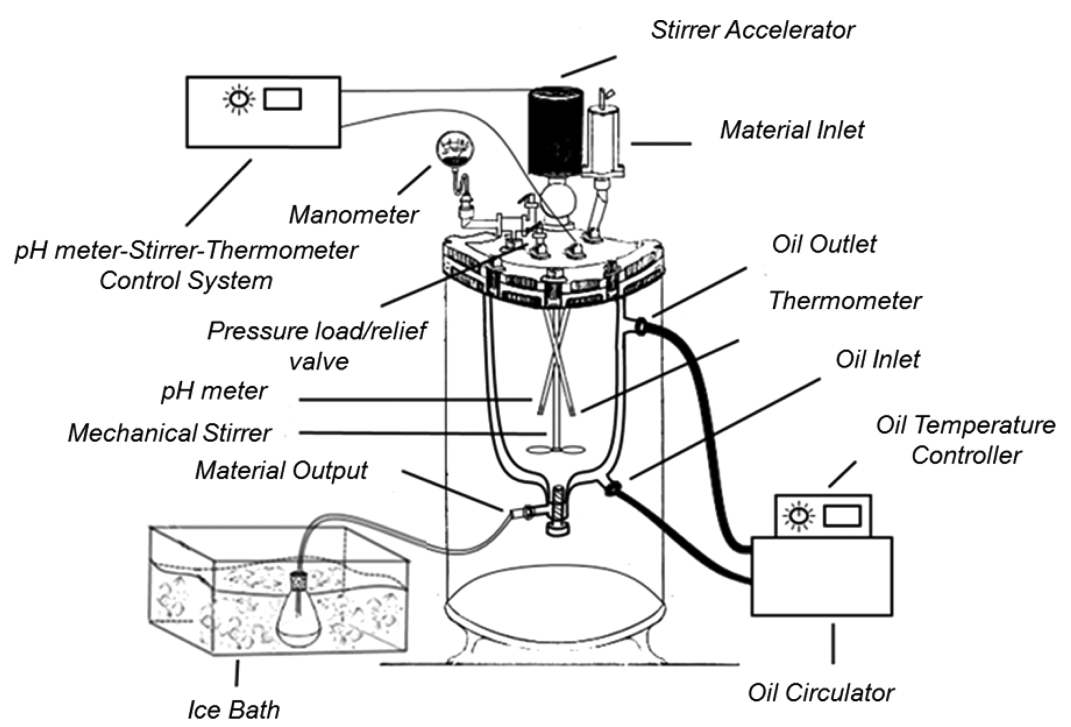

Figure 2. Schematic representation of the autoclave system.

Table 2. Initial Concentrations (ppm) of the Components in the Control Sample

\begin{tabular}{cccccccc} 
& {$\left[\mathrm{Fe}^{2+}\right]$} & {$\left[\mathrm{Mg}^{2+}\right]$} & {$\left[\mathrm{Ca}^{2+}\right]$} & {$\left[\mathrm{Na}^{+}\right]$} & {$\left[\mathrm{SiO}_{2}\right]$} & temperature $\left({ }^{\circ} \mathrm{C}\right)$ & pressure $(\mathrm{bar})$ \\
\multirow{2}{*}{ control } & 927 & 404 & 1330 & 1912 & 2000 & 137.6 & 3.2 \\
\hline
\end{tabular}

VSA ( 4 g, $7.6 \mathrm{mmol})$ and VPA $(0.82 \mathrm{~g}, 7.6 \mathrm{mmol})$ were dissolved in distilled water $(20 \mathrm{~mL})$. Afterward, the mixture was bubbled with $\mathrm{N}_{2}$ for $10 \mathrm{~min}$, and the reaction was initiated by APS $(34.7 \mathrm{mg}, 0.152$ mmol) addition. The mixture was stirred at $60{ }^{\circ} \mathrm{C}$ for $12 \mathrm{~h}$, and the product was obtained by precipitation in acetone. Precipitated poly(vinyl sulfonic acid-co-vinyl phosphonic acid) [P(VSA-co-VPA)] was observed as a white powder after drying at $45^{\circ} \mathrm{C}$ for $12 \mathrm{~h}$.

Terpolymer synthesis was carried out with AM $(0.71 \mathrm{~g}, 10 \mathrm{mmol})$, VPA $(1.08 \mathrm{~g}, 10 \mathrm{~mol})$, and VSA $(5.2 \mathrm{~g}, 10 \mathrm{mmol})$. All monomers were dissolved in $35 \mathrm{~mL}$ of distilled water and purged with $\mathrm{N}_{2}$ for $10 \mathrm{~min}$. APS $(68.4 \mathrm{mg}, 0.3 \mathrm{mmol})$ was used as an initiator, and the reaction was maintained at $60{ }^{\circ} \mathrm{C}$ for $12 \mathrm{~h}$. The mixture was added dropwise to acetone to precipitate the terpolymer, $\mathrm{P}(\mathrm{AM}-\mathrm{co}$-VSA-co-VPA), and the chains were obtained after drying at $45{ }^{\circ} \mathrm{C}$ for $24 \mathrm{~h}$. Experimental details of the polymer synthesis, including the amount of reactants, temperature, molar ratio of initiator, and product yield, are listed in Table 1.

2.2.2. Antiscaling Performance. A Buchi Glauster (Uster, Switzerland) autoclave reactor system was used for the synthesis of an artificial metal silicate scale (Figure 2). The reactor had three main components: glass chamber, circulator device, and monitoring part. The chamber had a closed container, liquid and gas inlets, a magnetic mixing motor, a thermometer, and a $\mathrm{pH}$ probe.

Antiscaling performance of the polymers was examined with the artificial brine recipe given in Table 2 . The scales were synthesized from a synthetic brine solution that contained equal volumes $(40 \mathrm{~mL})$ of $\mathrm{FeCl}_{2} \cdot 4 \mathrm{H}_{2} \mathrm{O}, \mathrm{MgCl}_{2} \cdot 6 \mathrm{H}_{2} \mathrm{O}, \mathrm{CaCl}_{2}, \mathrm{Na}_{2} \mathrm{CO}_{3}$, and $\mathrm{Na}_{2} \mathrm{SiO}_{3}$ solutions. Initially, artificial brine was injected into the autoclave, and the reaction was maintained at $137.6^{\circ} \mathrm{C}$ and $3.2 \mathrm{bar}$ for $45 \mathrm{~min}$. Polymer solutions $(50 \mathrm{~mL})$ were added to the mixture in various concentrations $(25,50$, and $100 \mathrm{ppm})$ during evacuation from the autoclave system. The mixture was cooled in an ice bath for $2 \mathrm{~h}$ after the polymers were added. The precipitate was isolated by centrifugation $(6000 \mathrm{rpm}$ for 30 $\mathrm{min}$ ), and the decantate was analyzed by inductively coupled plasma mass spectroscopy (ICP-MS).

The $\mathrm{pH}$ of brine was measured using a multiparameter meter (pHenomenal MU 6100 L, VWR International, Vienna, Austria). The mesurements were carried out both before and after the reaction and, additionally, after antiscalant treatment.

The criterion for success of a polymeric metal silicate inhibitor is the solubility of silica. To indicate this success mathematically, we used the following equation:

$$
n=\frac{C_{1}-C_{2}}{C_{\max }-C_{2}} \times 100
$$

where $C_{1}$ and $C_{2}$ refer to the $\mathrm{SiO}_{2}$ concentration in the presence and absence of the polymeric metal silicate inhibitor, respectively. The $\mathrm{SiO}_{2}$ concentration in the absence of metal cations is expressed as $C_{\max }$, which is experimentally measured as $408 \mathrm{ppm}$.

2.3. Characterization. Chemical structures of the obtained polymers were confirmed by ${ }^{13} \mathrm{C}$ and ${ }^{1} \mathrm{H}$ nuclear magnetic resonance (NMR) analysis, which was performed by a Varian V NMR 400 (Palo Alto, CA, U.S.A.). The effect of the polymers was investigated in both the decantate and precipitate.

In the decantate, $\mathrm{SiO}_{2}$ species were measured by the ultraviolet (UV) silica molybdate colorimetric method using a Hach DR 5000 instrument (London, U.K.) using the 656 Silica HR mode. Ammonium molybdate is associated with silica species for coloration. 
However, not only monomeric but dimeric or trimeric silica species also interact with molybdate and result in the same color in spectroscopy. This is because throughout the text, rather than soluble silica, we use molybdate-reactive silica to refer to all silica species giving response to ammonium molybdate. ${ }^{35,36}$ The concentration of the cations in the decantate $\left(\mathrm{Na}^{+}, \mathrm{Ca}^{2+}, \mathrm{Mg}^{2+}\right.$, and $\left.\mathrm{Fe}^{2+, 3+}\right)$ was measured using ICP-MS on an Agilent $7500 \mathrm{CE}$ Octopole instrument (Santa Clara, CA, U.S.A.). Elemental composition of the precipitates is determined via X-ray fluorescence spectroscopy (XRF, Spectro iQ II, Kleve, Germany) (mass loss on fusion).

The molecular weights of the polymers were measured by the static light scattering method applying the Rayleigh equation at various concentrations. For a calculation, the differential refractive index increment $(\mathrm{d} n / \mathrm{d} C)$ of each polymer was measured by an Abbe-type refractometer.

\section{RESULTS AND DISCUSSION}

3.1. Precipitation of Metal Silicate. The strategy in the determination of antiscaling performance is based on monitoring the concentration of silicic acid and metal cations in the leftover decantate solution after the isolation of solid precipitates from the autoclave reactor. The fabrication of $(\mathrm{Fe}$, $\mathrm{Mg}$ ) silicate was as reported in our previous work. ${ }^{37}$ Briefly, chloride salts of $\mathrm{Fe}$ and $\mathrm{Mg}$ were treated with an aqueous solution of $\mathrm{Na}_{2} \mathrm{SiO}_{3}$. The concentration employed in our study as a model system simulated the ion concentrations from the Tuzla Geothermal Power Plant in the northwest part of Turkey. The reaction was carried out under the following conditions: 3.2 bar (well-head pressure) and $137{ }^{\circ} \mathrm{C}$ (well-head temperature). When the reaction was completed, the pressurized mixture was transferred through Teflon piping into a plastic flask sitting in an ice-water bath. Because solubility is a function of the temperature, a sudden decrease of the temperature causes uncontrolled precipitation, as would happen in a geothermal field. The injection of the antiscalant agent before taking the mixture out from the system is important because the formation of the scale in real field conditions occurs in a similar way. The decrease of the pressure and temperature takes place suddenly after the flushing point, and the deposits form in a very short time period when brine is pumped to the ground. The reaction duration in the autoclave reactor was approximately $45 \mathrm{~min}$.

Figure 3 presents the X-ray diffraction (XRD) patterns and scanning electron microscopy (SEM) images of representative precipitates. The diffractogram shows that the precipitate has an amorphous nature along with low-intensity $\mathrm{NaCl}$ and magnetite reflections. The electron micrograph depicts that the metal silicate scaling is composed of sub-micrometer-sized aggregates of sharp flakes. ${ }^{38}$ The structure and morphology of the precipitations are more or less similar; no remarkable difference was obtained in the formation of silicate obtained in the presence of metal cations.

3.2. Synthesis of Polymeric Antiscalants. In this study, three vinyl molecules were used as comonomers to achieve a diverse selection of polymeric antiscalants. Chemical structures were determined by ${ }^{13} \mathrm{C}$ and ${ }^{1} \mathrm{H}$ NMR analysis. Upon polymerization, shifting of the vinyl group to the aliphatic region was observed. This result suggests successful formation of polymeric molecules. NMR spectra of the polymers are given in Figures S3-S6 of the Supporting Information. The composition of the copolymers was determined by the integration of the signals that belonged to the monomeric species. The molecular weights and monomer ratios of each polymer are given in Table 3.

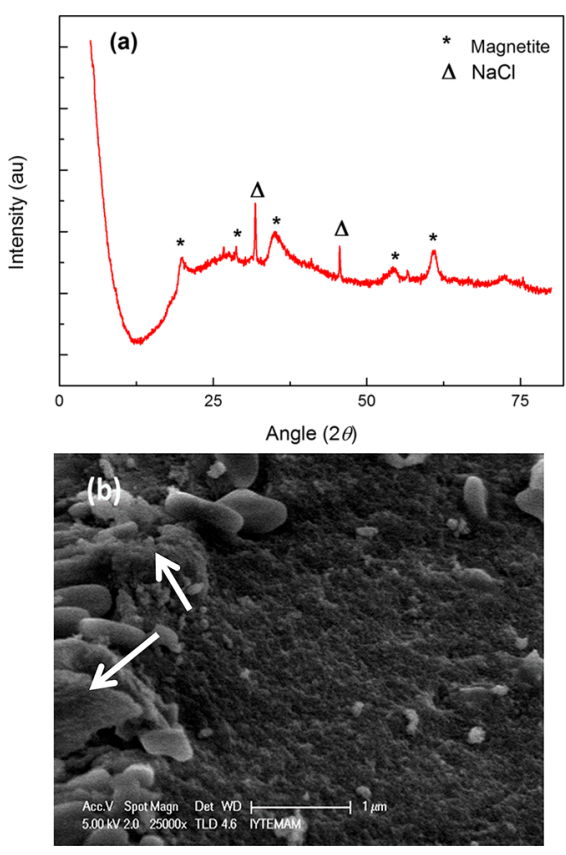

Figure 3. (a) XRD pattern and (b) SEM image of ( $\mathrm{Fe}, \mathrm{Mg}$ ) silicate scale. The markers ( $*$ and $\triangle$ ) represent magnetite and $\mathrm{NaCl}$ reflections, respectively. The white arrows show the $\mathrm{NaCl}$ crystals.

3.2.1. AM. ${ }^{1} \mathrm{H}$ NMR (400 $\left.\mathrm{MHz}, \mathrm{D}_{2} \mathrm{O}, 295 \mathrm{~K}\right) \delta$ (ppm): $6.202\left(=\mathrm{CH}_{2}, \mathrm{~m}\right), 5.709,5.681(=\mathrm{CH}-, \mathrm{d}) .{ }^{13} \mathrm{C} \mathrm{NMR}(400$ $\left.\mathrm{MHz}, \mathrm{D}_{2} \mathrm{O}, 295 \mathrm{~K}\right) \delta(\mathrm{ppm}): 170.734(\mathrm{C}=\mathrm{O}), 129.365$ (= $\mathrm{CH}-), 128.391\left(=\mathrm{CH}_{2}\right)$. Polyacrylamide: ${ }^{1} \mathrm{H}$ NMR $(400$ $\left.\mathrm{MHz}, \mathrm{D}_{2} \mathrm{O}, 295 \mathrm{~K}\right) \delta$ (ppm): 2.196, 2,066 (-CHCO-, s), 1.624-1.511 (- $\left.\mathrm{CH}_{2}-, \mathrm{s}\right) .{ }^{13} \mathrm{C} \mathrm{NMR}\left(400 \mathrm{MHz}, \mathrm{D}_{2} \mathrm{O}, 295 \mathrm{~K}\right)$ $\delta(\mathrm{ppm}): 179.34(\mathrm{C}=\mathrm{O}), 42.182$ (-CHCO-), 35.499 $\left(-\mathrm{CH}_{2}-\right)$.

3.2.2. VSA. ${ }^{1} \mathrm{H}$ NMR ( $\left.400 \mathrm{MHz}, \mathrm{D}_{2} \mathrm{O}, 295 \mathrm{~K}\right) \delta$ (ppm): 6.544 (=CHS-, q), $5.941\left(=\mathrm{CH}_{2}, \mathrm{~d}\right), 5.678\left(=\mathrm{CH}_{2}, \mathrm{~d}\right) .{ }^{13} \mathrm{C}$ NMR $\left(400 \mathrm{MHz}, \mathrm{D}_{2} \mathrm{O}, 295 \mathrm{~K}\right) \delta(\mathrm{ppm}): 137.176\left(=\mathrm{CH}_{2}\right)$, 122.532 (=CH-). PVSA: ${ }^{1} \mathrm{H}$ NMR (400 MHz, $\left.\mathrm{D}_{2} \mathrm{O}, 295 \mathrm{~K}\right)$ $\delta(\mathrm{ppm}): 3.788$ (-CHS-, t), $3.243\left(-\mathrm{CH}_{2}-, \mathrm{s}\right), 3.109$ $\left(-\mathrm{CH}_{2}-, \mathrm{t}\right) \cdot{ }^{13} \mathrm{C}$ NMR $\left(400 \mathrm{MHz}, \mathrm{D}_{2} \mathrm{O}, 295 \mathrm{~K}\right) \delta(\mathrm{ppm})$ : 65.591 (-CHS -$), 50.376\left(-\mathrm{CH}_{2}-\right)$. The reaction was approved by the disappearance of vinyl signals in both ${ }^{13} \mathrm{C}$ and ${ }^{1} \mathrm{H}$ NMR.

3.2.3. VPA. ${ }^{1} \mathrm{H}$ NMR ( $\left.400 \mathrm{MHz}, \mathrm{D}_{2} \mathrm{O}, 295 \mathrm{~K}\right) \delta$ (ppm): 5.92, 5.84 (=CH-P, m), 5.75, $5.725\left(=\mathrm{CH}_{2}, \mathrm{~d}\right) .{ }^{13} \mathrm{C} \mathrm{NMR}$ $\left(400 \mathrm{MHz}, \mathrm{D}_{2} \mathrm{O}, 295 \mathrm{~K}\right) \delta(\mathrm{ppm}): 133.6$ (=CHP), 127.88, $126.12\left(=\mathrm{CH}_{2}\right)$. PVPA: ${ }^{1} \mathrm{H}$ NMR $\left(400 \mathrm{MHz}, \mathrm{D}_{2} \mathrm{O}, 295 \mathrm{~K}\right) \delta$ (ppm): 1.9, 1.76, 1.62, 1.35 (-CH-, s), $2.2\left(-\mathrm{CH}_{2}-, \mathrm{s}\right) .{ }^{13} \mathrm{C}$ NMR (400 MHz, $\left.\mathrm{D}_{2} \mathrm{O}, 295 \mathrm{~K}\right) \delta$ (ppm): 71.9, 62.3 (-CHP-), 32.97, 31.55, $29.7\left(-\mathrm{CH}_{2-}\right)$.

3.2.4. PAM-Co-VSA. ${ }^{1} \mathrm{H}$ NMR (400 MHz, $\left.\mathrm{D}_{2} \mathrm{O}, 295 \mathrm{~K}\right) \delta$ (ppm): 3.2 (-SCH-, m), 2.205, 2.049 (-COCH-, m), 1.623, $1.586\left(-\mathrm{CH}_{2}-, \mathrm{m}\right)$. PAM-co-VPA: ${ }^{1} \mathrm{H}$ NMR $\left(400 \mathrm{MHz}, \mathrm{D}_{2} \mathrm{O}\right.$, $295 \mathrm{~K}) \delta(\mathrm{ppm}): 3.5$ (-CHCO, q), 2.199, 2.065 (-CHP, s), $1.797,1.623,1.510\left(-\mathrm{CH}_{2}, \mathrm{~s}\right), 1.019\left(-\mathrm{CH}_{2}, \mathrm{t}\right)$. PVSA-co-VPA: ${ }^{1} \mathrm{H}$ NMR (400 MHz, $\left.\mathrm{D}_{2} \mathrm{O}, 295 \mathrm{~K}\right) \delta$ (ppm): 2.774, 2.550 (-CHP, s), 2.112, 1.903, $1.607\left(-\mathrm{CH}_{2}, \mathrm{~s}\right), 1.930$ (-CHS-, s). PAM-co-VSA-co-VPA: ${ }^{1} \mathrm{H}$ NMR (400 MHz, $\left.\mathrm{D}_{2} \mathrm{O}, 295 \mathrm{~K}\right) \delta$ (ppm): 3.5 (-CHCO, q), 2.194, 2.086 (-CHP-, s), 2.074 (-CHS-, s), 1.771, 1.623, $1.514\left(-\mathrm{CH}_{2}, \mathrm{~s}\right), 1.026\left(-\mathrm{CH}_{2}, \mathrm{t}\right)$.

3.3. Effect of Polymeric Antiscalants on the Formation of Metal Silicates. All antiscalant molecules were stable under 
Table 3. Molecular Properties and Efficiency of Silicate Solubility of the Polymers and Copolymers

\begin{tabular}{|c|c|c|c|c|c|}
\hline & $M_{\mathrm{w}}(\mathrm{kDa})$ & feed composition $(\mathrm{mol} / \mathrm{mol})$ & composition of the backbone $(\mathrm{mol} / \mathrm{mol})$ & dosage (ppm) & silica inhibition efficiency (\%) \\
\hline \multirow[t]{3}{*}{ PAM } & 43.1 & 1 & 1 & 25 & 4.8 \\
\hline & & & & 50 & 19.5 \\
\hline & & & & 100 & 20.3 \\
\hline \multirow[t]{3}{*}{ PVSA } & 48.1 & 1 & 1 & 25 & 32.7 \\
\hline & & & & 50 & 24 \\
\hline & & & & 100 & 8.2 \\
\hline \multirow[t]{3}{*}{ PVPA } & 22.7 & 1 & 1 & 25 & 0.3 \\
\hline & & & & 50 & 14.2 \\
\hline & & & & 100 & 17.2 \\
\hline \multirow[t]{3}{*}{$\mathrm{P}(\mathrm{AM}-c o-\mathrm{VSA})$} & 85.4 & $1: 1$ & $0.5: 0.5$ & 25 & -11.2 \\
\hline & & & & 50 & 2.2 \\
\hline & & & & 100 & 22.9 \\
\hline \multirow[t]{3}{*}{$\mathrm{P}(\mathrm{VSA}-c o-\mathrm{VPA})$} & 78.7 & $1: 1$ & $0.2: 0.8$ & 25 & 21 \\
\hline & & & & 50 & 33.8 \\
\hline & & & & 100 & 25.5 \\
\hline \multirow[t]{3}{*}{$\mathrm{P}(\mathrm{AM}-c o-\mathrm{VPA})$} & 23.6 & $1: 1$ & $0.7: 0.3$ & 25 & 26.3 \\
\hline & & & & 50 & 25.1 \\
\hline & & & & 100 & 15.7 \\
\hline \multirow[t]{3}{*}{$\mathrm{P}(\mathrm{AM}-c o-\mathrm{VSA}-c o-\mathrm{VPA})$} & 51.5 & $1: 1: 1$ & $0.25: 0.25: 0.5$ & 25 & 23.6 \\
\hline & & & & 50 & 19.9 \\
\hline & & & & 100 & 19.9 \\
\hline
\end{tabular}
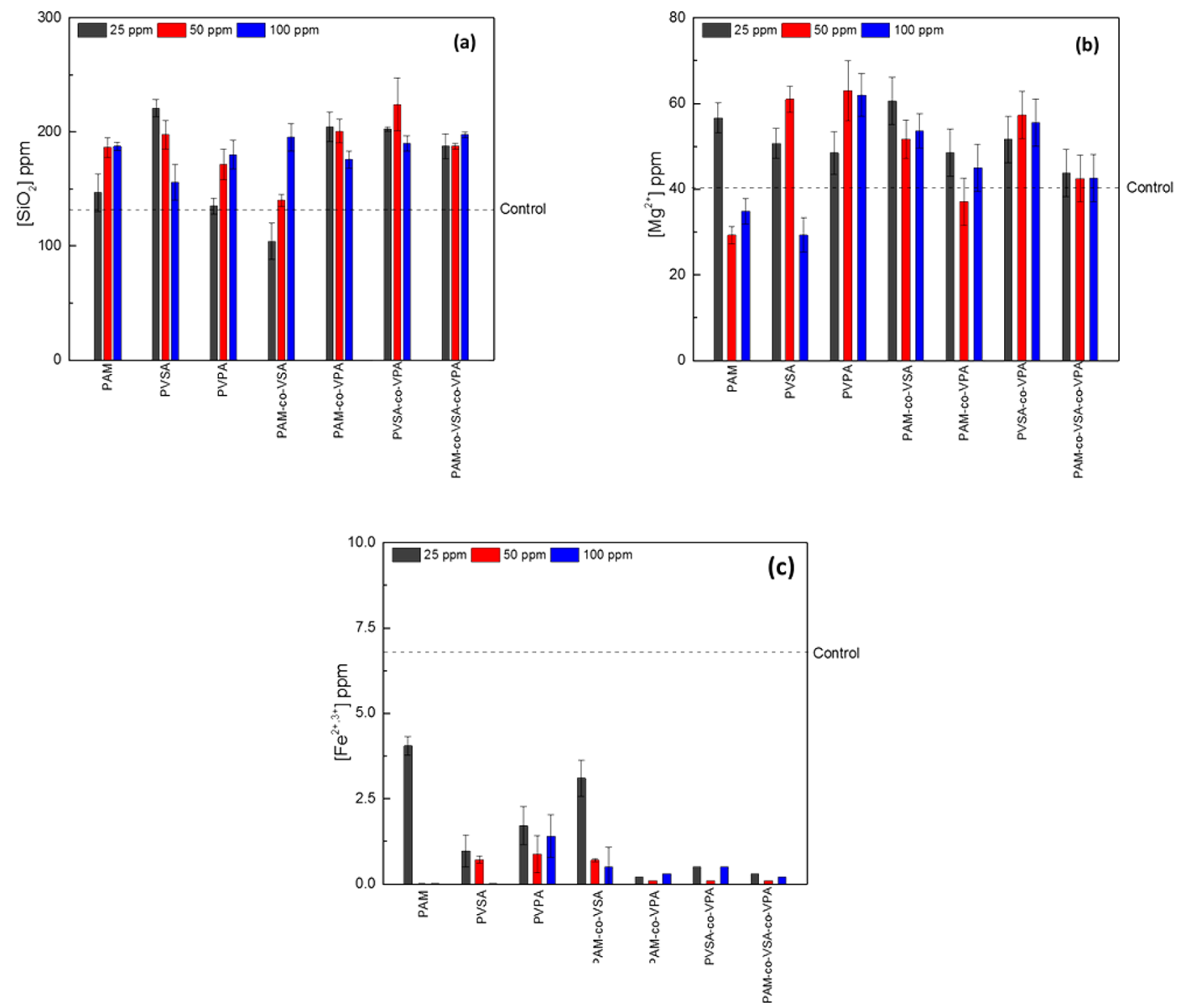

Figure 4. Solubility profiles of (a) molybdate-reactive $\mathrm{SiO}_{2},(\mathrm{~b}) \mathrm{Mg}^{2+}$, and (c) $\mathrm{Fe}^{2+, 3+}$ in the presence of various inhibitors at different dosages. The dashed line refers to the control sample.

the reaction conditions. There is no degradation information regarding the polymers in the reaction mixture (see the Supporting Information). The reaction performed with neat artificial brine was used as the control trial for comparison to runs in the presence of antiscalants. Figure $4 \mathrm{a}$ shows the molybdate-reactive silica concentration obtained from the trials 
performed with various dosages of antiscalants. The dashed line in the plot refers to the control test (no antiscalant agent). The level of molybdate-reactive silica in the control trial shows the solubility limit of silicic acid. This result was consistent with the literature. ${ }^{39}$ Different dosages were employed: 25,50 , and 100 ppm. A general observation is that, in the presence of antiscalant agents, the level of silicic acid was higher than the solubility limit of silicic acid; i.e., all of the synthesized polymeric antiscalants demonstrated a favorable effect to some extent.

The solubility of $\mathrm{SiO}_{2}$ increased as the dosage of the PAM and PVPA homopolymers increased from 25 to $100 \mathrm{ppm}$. The maximum level of solubility was approximately $180 \mathrm{ppm}$. This reached to $220 \mathrm{ppm}$ when PVSA was employed at $25 \mathrm{ppm}$. VSA seems to be a promising functional monomer for increasing the solubility of silica. As the dosage increased to $100 \mathrm{ppm}$, the concentration of molybdate-reactive silica decreased. The reduction of silica levels as the dosage of PVSA increased was probably due to flocculation of silica in the presence of the polymeric antiscalant. Nevertheless, this was still above the limit of silica solubility (the dashed line parallel to the $x$ axis is nearly $130 \mathrm{ppm}$ ). Among the copolymers employed, P(VSA-co-VPA) exhibited the best performance, particularly at $50 \mathrm{ppm}$ dosage, where the solubility level increased to $225 \mathrm{ppm}$. The terpolymer, led to a solubility level of $200 \mathrm{ppm}$. However, no linear relationship between dosage and performance was observed. The reason for independence of inhibition from the dosage may be the rapid formation of the precipitates in a random manner; therefore, the inhibitors do not have sufficient time to function. The antiscaling performances of all trials were calculated according to eq 1 , and results are presented in Table 3 . The efficiency value was parallel to the solubility levels mentioned above. The maximum performance for improving silica solubility was more than $33 \%$ for the case of $\mathrm{P}$ (VSA-co-VPA) at $50 \mathrm{ppm}$ dosage.

The antiscalant efficiency was also studied for metal cations $\left(\mathrm{Fe}^{2+, 3+}\right.$ and $\left.\mathrm{Mg}^{2+}\right)$. The effect of the antiscalants on the $\mathrm{Mg}^{2+}$ concentration varied depending upon the dosage and the chemistry of the polymer (Figure $4 \mathrm{~b}$ ). The level of the $\mathrm{Mg}^{2+}$ concentration was around $40 \mathrm{ppm}$. The $\mathrm{Mg}^{2+}$ concentration increased for all of the antiscalant polymers employed; however, the best efficiency for $\mathrm{Mg}^{2+}$ solubility is achieved using $\mathrm{P}(\mathrm{AM}-\mathrm{co}-\mathrm{VSA})$ and $\mathrm{P}(\mathrm{AM}-\mathrm{co}-\mathrm{VPA})$ at $60 \mathrm{ppm}$ solubility at 50 and $100 \mathrm{ppm}$ dosages, respectively. On the other hand, the antiscalant agents were not found to be as promising for $\mathrm{Fe}^{2+}$ as they were for silicate and $\mathrm{Mg}^{2+}$. The initial concentration of iron species were $7 \mathrm{ppm}$ (control). After the precipitation reaction was completed, the concentration was reduced between 3.0 and $0.1 \mathrm{ppm}$. P(AM-co-VSA) showed a slight effect on Fe species solubilization (Figure 4c). Note that the concentration of total Fe was much smaller than that of the other species $\left(\mathrm{SiO}_{2}=200 \mathrm{ppm}\right.$, and $\left.\mathrm{Mg}^{2+}=40 \mathrm{ppm}\right)$ and had only a minor contribution to the amount of the precipitates.

The efficiency of these polymeric antiscalants was also examined on simple silica polymerization (without metal cations). The identical autoclave reactions were performed in the absence of metal salts. The initial silica concentration was $2000 \mathrm{ppm}$, and the concentration of molybdate-reactive silica was reduced to nearly $400 \mathrm{ppm}$. The rest of $\mathrm{Na}$ silicate contributed to the precipitate. Considering that the level of silica solubility was reduced to $130 \mathrm{ppm}$ in the presence of chloride salts of $\mathrm{Mg}$ and $\mathrm{Fe}$, it is obvious that the metal cations catalyze the polymerization of silica (not a surprising result). ${ }^{40}$
When the polymeric antiscalants were used in their own best performance dosages, from Table 3, the level of solubility fell into the $360 \pm 60 \mathrm{ppm}$ range (Figure 5), which was even lower

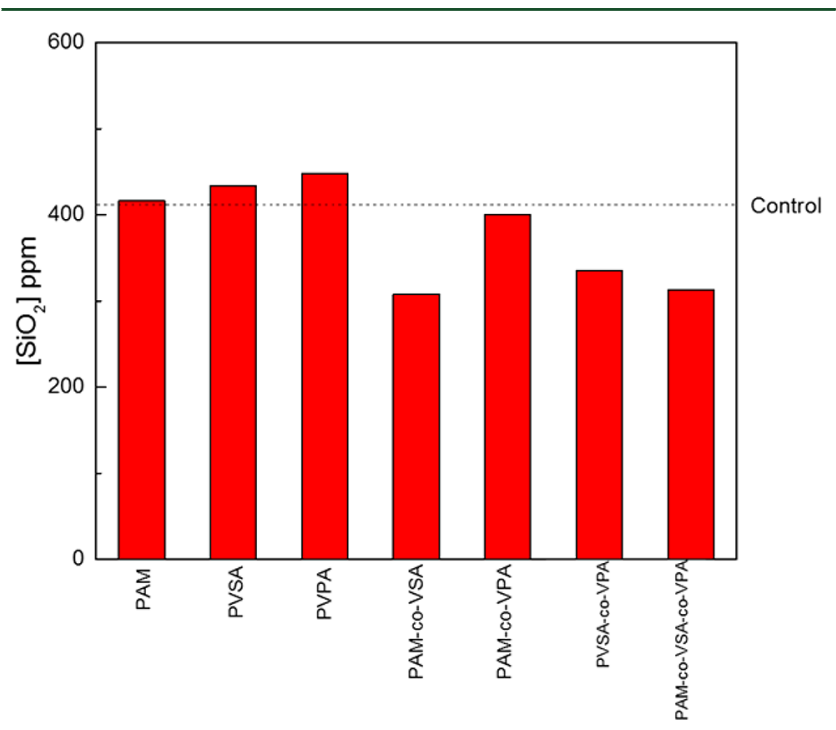

Figure 5. Molybdate-reactive $\mathrm{SiO}_{2}$ concentration in the various antiscalants. Only $\mathrm{Na}$ silicate is used as a reactant without having metal salts. For each polymer, the most effective dosage in brine trials was used (PAM, 100 ppm; PVSA, 25 ppm; PVPA, 100 ppm; PAM-co-VSA, 100 ppm; PAM-co-VPA, 25 ppm; PVSA-co-VPA, 50 ppm; and PAMco-VSA-co-VPA, 100 ppm).

than the value obtained in their absence (400 ppm). The corresponding antiscalant efficiency for mere silica (without metals) appears in the range from -6.2 to $2.5 \%$. This result may hint at the antiscaling working mechanism of the polymers. Acidic comonomers are negatively charged in aqueous solution. Thus, electrostatic attraction between the negatively charged comonomer species and positively charged metallic/silicic cations may have occurred. This result suggests that the polymeric antiscalants show no remarkable effect on the solubility of silica; they are particularly efficient for metal silicates likely through chelation.

The $\mathrm{pH}$ of unreacted brine shows slightly alkaline behavior $\left(\mathrm{pH} 8.5\right.$ at $\left.25{ }^{\circ} \mathrm{C}\right)$ most likely as a result of the presence of $\mathrm{Na}_{2} \mathrm{CO}_{3}$. However, $\mathrm{pH}$ of the decantate after taking place in the reaction decreases to 5.86 at $75{ }^{\circ} \mathrm{C}$. The difference between before and after the reaction may be attributed to the selfionization of water at different temperatures. ${ }^{41} \mathrm{pH}$ measurements were also carried out for the decantates obtained in the presence of antiscalants. There is no considerable change in $\mathrm{pH}$ when PAM and PVSA (100 ppm) were employed, with $\mathrm{pH}$ 6.09 and 5.95 at room temperature, respectively. On the other hand, PVPA (100 ppm) treatment caused $\mathrm{pH}$ to decrease to 4.45. It is well-known that $\mathrm{pH}$ is an important parameter for the formation of unary metal silicates. ${ }^{42-44}$ However, the brine used in this study has a more complex system. XRF were used for the determination of elemental composition of the precipitate. The results are given in number of moles of components $\left(\mathrm{Mg}, \mathrm{Fe}\right.$, and $\left.\mathrm{SiO}_{2}\right)$ in Table 4. The stoichiometry cannot be able to be categorized under any of the known groups of metal silicates.

Silicate deposition is based on the condensation of silicic acid. The condensation reaction occurs in three dimensions, forming a network, where silicon is bonded to four oxygen 
Table 4. Elemental Composition of the Precipitates Determined by XRF

\begin{tabular}{lrccc} 
& & \multicolumn{3}{c}{ number of moles in scale } \\
\cline { 3 - 5 } & dosage & $\mathrm{Fe}$ & $\mathrm{Mg}$ & $\mathrm{SiO}_{2}$ \\
PAM & 100 & 0.118 & 0.097 & 0.377 \\
PVSA & 25 & 0.162 & 0.071 & 0.335 \\
PVPA & 100 & 0.111 & 0.065 & 0.329 \\
PAM-co-VSA & 100 & 0.105 & 0.046 & 0.334 \\
PVSA-co-VPA & 50 & 0.110 & 0.057 & 0.307 \\
PAM-co-VPA & 25 & 0.131 & 0.055 & 0.368 \\
PAM-co-VSA-co-VPA & 25 & 0.119 & 0.052 & 0.313 \\
\hline
\end{tabular}

atoms in a tetrahedral configuration. The three-dimensional network forms a critical nucleus that is not very thermodynamically stable against dissolution. When the size of silica exceeds a critical size, estimated to be approximately $5 \mathrm{~nm}$, the nucleus grows and forms silica colloids. The uncontrolled aggregation and agglomeration of the silica colloids cause the formation of undesirable silica deposits. The metal cations may bridge two silica colloids. There are two possible mechanisms for the minimization of metal silicate deposits: (i) chelating of monomeric silica sources and (ii) dispersion of silica particles. The former prevents the precipitation of colloids by reducing the concentration of ions by chelating. On the other hand, the latter stabilizes the already formed colloids, avoiding agglomeration/clustering. The mechanism of silicate mitigation in this study seems to be based only on mechanism i because the antiscalants are only effective for metal silicates. In their application to silica (without metals), no improvement was observed. The solubility level of the silica increased; however, no colloidal stability was detected for the polymeric antiscalants. This result rules out mechanism ii.

The dosage had a strong influence on the performance of the antiscalants. Although the antiscalants had a remarkable influence on the solubility of silicate, they had almost no effect on solubility at higher dosages. For instance, increasing the dosage of PVSA from 25 to $100 \mathrm{ppm}$ reduced the efficiency from 32.7 to 8.2. Flocculation can be the main explanation for the decrease of efficiency at higher polymeric antiscalant dosages. It can be defined as the aggregation/agglomeration of silica colloids induced by the presence of polymeric compounds. When a polymeric chain interacts with more than one colloid, colloid clustering occurs. The interaction of silica colloids with the antiscalants is a matter of the molecular weight of the polymer and its chemical affinity (enthalpic interaction) to the polymer. All of the comonomers used in this study have strong interactions with silica; therefore, the molecular weight could be the determining parameter for the flocculation mechanism. The size of the colloids was approximately $35 \mathrm{~nm}$ in diameter; on the other hand, the molecular weights of the polymers were $30-85 \mathrm{kDa}$. A chain consisting of $n$ bonds, each of length $l$, gives a mean square of the distance $r$ between the ends of the chain through the familiar relation $\left\langle r^{2}\right\rangle=C n l^{2}$, where $C$ is a constant for polymers. The end-to-end distance is roughly estimated to be between 5 and $15 \mathrm{~nm} .{ }^{45}$ It is highly possible that the chains can interact with more than one colloid and undergo undesirable flocculation at high dosages.

\section{CONCLUSION}

Scaling is a major obstacle in both petroleum and geothermal fields. It is essential to prevent scale deposits, which are extremely tenacious and highly insulating. To develop soft organic antiscalants, homo- and copolymers of AM, VSA, and VPA were obtained by free radical solution polymerization and the antiscalant performance of the resulting polymers was examined. The precipitation of metal silicates was carried out in an autoclave system to simulate real field conditions. The performance was evaluated by monitoring the ion concentration in the decantate after centrifugation of the precipitates. The synthesis of VSA-rich copolymers shows a promising antiscalant performance for $(\mathrm{Fe}, \mathrm{Mg})$ silicate precipitates because the polymers offer remarkable performance, particularly against metal silicates. The solubility improved to 225 ppm when $\mathrm{P}$ (VSA-co-VPA) was employed at $50 \mathrm{ppm}$. The polymeric molecules presented here can potentially be used as antiscalants along with a complementary dispersion agent because the working mechanism seems to be based on the inhibition (chelating) of silicate rather than the dispersion of colloids.

\section{ASSOCIATED CONTENT}

\section{S Supporting Information}

The Supporting Information is available free of charge on the ACS Publications website at DOI: 10.1021/acs.energyfuels.7b01221.

Fourier transform infrared (FTIR) and NMR spectra of the monomers and polymers, correlation plot of the temperature and $\mathrm{pH}$, and Debye plots of the polymers employed (PDF)

\section{AUTHOR INFORMATION}

\section{Corresponding Author}

*Telephone: +90-232-750-7511. Fax: +90-232-750-7509. Email: mdemir@iyte.edu.tr.

ORCID

Mustafa M. Demir: 0000-0003-1309-3990

Notes

The authors declare no competing financial interest.

\section{ACKNOWLEDGMENTS}

The authors gratefully acknowledge funding from the Scientific and Technological Research Council of Turkey (TÜBİTAK, 1001 114Z940). The authors are grateful to Tuzla GPP for supplying the natural deposits and brine.

\section{REFERENCES}

(1) Oddo, J.; Tomson, M. SPE Prod. Facil. 1994, 9, 47-54.

(2) Neville, A. Energy Fuels 2012, 26, 4158-4166.

(3) Mady, M. F.; Bagi, A.; Kelland, M. A. Energy Fuels 2016, 30, 9329-9338.

(4) Demadis, K. D.; Somara, M.; Mavredaki, E. Ind. Eng. Chem. Res. 2012, 51, 2952-2962.

(5) Demadis, K. D.; Mavredaki, E.; Somara, M. Ind. Eng. Chem. Res. 2011, 50, 13866-13876.

(6) Demadis, K. D.; Mavredaki, E.; Somara, M. Ind. Eng. Chem. Res. 2011, 50, 12587-12595.

(7) Baba, A.; Demir, M. M.; Koç, G. A.; Tuğcu, C. Geothermics 2015, $53,406-412$.

(8) Honegger, J.; Czernichowski-Lauriol, I.; Criaud, A.; Menjoz, A.; Sainson, S.; Guezennec, J. Geothermics 1989, 18, 137-144.

(9) Pátzay, G.; Kármán, F. H.; Póta, G. Geothermics 2003, 32, 627638.

(10) Stáhl, G.; Pátzay, G.; Weiser, L.; Kálmán, E. Geothermics 2000, 29, 105-119. 
(11) Gunnlaugsson, E.; Einarsson, A. r. Geothermics 1989, 18, 113120.

(12) Kristmannsdóttir, H. Geothermics 1989, 18, 183-190.

(13) Ghouil, B.; Harabi, A.; Bouzerara, F.; Boudaira, B.; Guechi, A.; Demir, M. M.; Figoli, A. Mater. Charact. 2015, 103, 18-27.

(14) Chauhan, K.; Patiyal, P.; Chauhan, G. S.; Sharma, P. Water Res. 2014, 56, 225-233.

(15) Zhang, B.-R.; Chen, Y.-N.; Li, F.-T. Colloids Surf., A 2011, 385, $11-19$.

(16) Brinker, C. J.; Scherer, G. W. Sol-Gel Science: The Physics and Chemistry of Sol-Gel Processing; Academic Press: London, U.K., 2013.

(17) Sjöberg, S. J. Non-Cryst. Solids 1996, 196, 51-57.

(18) Amjad, Z.; Demadis, K. D. Mineral Scales and Deposits: Scientific and Technological Approaches; Elsevier: Amsterdam, Netherlands, 2015.

(19) Gallup, D. L. Geothermics 2002, 31, 415-430.

(20) Gallup, D. L.; Barcelon, E. Geothermics 2005, 34, 756-771.

(21) Ketsetzi, A.; Stathoulopoulou, A.; Demadis, K. D. Desalination 2008, 223, 487-493.

(22) Demadis, K. D. J. Chem. Technol. Biotechnol. 2005, 80, 630-640.

(23) Neofotistou, E.; Demadis, K. D. Colloids Surf., A 2004, 242, 213-216.

(24) Demadis, K. D.; Mavredaki, E.; Stathoulopoulou, A.; Neofotistou, E.; Mantzaridis, C. Desalination 2007, 213, 38-46.

(25) Demadis, K. D.; Neofotistou, E. Mater. Perform. 2004, 43, 3842.

(26) Demadis, K. D.; Stathoulopoulou, A. Ind. Eng. Chem. Res. 2006, 45, 4436-4440.

(27) Demadis, K. D.; Neofotistou, E.; Mavredaki, E.; Tsiknakis, M.; Sarigiannidou, E.-M.; Katarachia, S. D. Desalination 2005, 179, 281295.

(28) Rivas, B. L.; Pereira, E.; Gallegos, P.; Homper, D.; Geckeler, K. E. J. Appl. Polym. Sci. 2004, 92, 2917-2922.

(29) Palencia, M.; Rivas, B. L.; Pereira, E. J. Membr. Sci. 2009, 345, 191-200.

(30) Girma, K.; Lorenz, V.; Blaurock, S.; Edelmann, F. T. Inorg. Chim. Acta 2006, 359, 364-368.

(31) Girma, K.; Lorenz, V.; Blaurock, S.; Edelmann, F. T. Coord. Chem. Rev. 2005, 249, 1283-1293.

(32) Okayasu, T.; Saito, K.; Nishide, H.; Hearn, M. T. Chem. Commun. 2009, 4708-4710.

(33) Macarie, L.; Ilia, G. Prog. Polym. Sci. 2010, 35, 1078-1092.

(34) Bingöl, B.; Meyer, W. H.; Wagner, M.; Wegner, G. Macromol. Rapid Commun. 2006, 27, 1719-1724.

(35) Icopini, G. A.; Brantley, S. L.; Heaney, P. J. Geochim. Cosmochim. Acta 2005, 69, 293-303.

(36) Preari, M.; Spinde, K.; Lazic, J. 1.; Brunner, E.; Demadis, K. D. J. Am. Chem. Soc. 2014, 136, 4236-4244.

(37) Çelik, A.; Topçu, G.; Baba, A.; Akdogan, Y.; Şentürk, U.; Demir, M. M. Geothermics 2017, 69, 65-73.

(38) Demir, M. M.; Baba, A.; Atilla, V.; Inanll, M. Geothermics 2014, 50, 1-9.

(39) Neofotistou, E.; Demadis, K. D. Desalination 2004, 167, 257272.

(40) Gallup, D. L.; Sugiaman, F.; Capuno, V.; Manceau, A. Appl. Geochem. 2003, 18, 1597-1612.

(41) Bandura, A. V.; Lvov, S. N. J. Phys. Chem. Ref. Data 2006, 35, $15-30$.

(42) Demadis, K. D.; Ketsetzi, A.; Sarigiannidou, E.-M. Ind. Eng. Chem. Res. 2012, 51, 9032-9040.

(43) Gorrepati, E. A.; Wongthahan, P.; Raha, S.; Fogler, H. S. Langmuir 2010, 26, 10467-10474.

(44) Valliant, E. M.; Turdean-Ionescu, C. A.; Hanna, J. V.; Smith, M. E.; Jones, J. R. J. Mater. Chem. 2012, 22, 1613-1619.

(45) Flory, P. J. Nobel Lecture, 1974; pp 1-22. 